\title{
Performance of black soldier fly frass fertiliser on maize (Zea mays L.) growth, yield, nutritional quality, and economic returns
}

\author{
C.M. Tanga ${ }^{1 *}$ iD, D. Beesigamukama ${ }^{1,2^{*}}$, M. Kassie ${ }^{1}$, P.J. Egonyu ${ }^{1}$, Changeh J. Ghemoh ${ }^{3}$, Kiatoko Nkoba ${ }^{1}$, \\ S. Subramanian ${ }^{1}$, A.O. Anyega ${ }^{1,4}$ and S. Ekesi ${ }^{1}$ \\ ${ }^{1}$ International Centre for Insect Physiology and Ecology, P.O. Box 30772-00100, Nairobi, Kenya; ${ }^{2}$ Department of Crop \\ Production and Management, Busitema University, P.O. Box 236 Tororo, Uganda; ${ }^{3}$ Centre for African Bio-Entrepreneurship \\ (CABE), P.O. Box 25535-00603, Lavington, Nairobi, Kenya; ${ }^{4}$ Department of Agricultural Science and Technology, Kenyatta \\ University, P.O. Box 43844-00100 Nairobi, Kenya; ctanga@icipe.org; dbeesigamukama@icipe.org; dbesiga@gmail.com
}

Received: 26 January 2021 / Accepted: 2 June 2021

(c) 2021 Wageningen Academic Publishers

OPEN ACCESS CC (i) RESEARCH ARTICLE

\begin{abstract}
Although the black soldier fly frass fertiliser (BSFFF) is globally recognised as a promising and potential high-quality organic fertiliser, there is inadequate information on its impact on the growth performance and nutritional status of maize. Furthermore, no information exist on their combination with mineral fertiliser (NPK) as well as economic impact on maize production. This study evaluated the comparative impact of BSFFF, NPK and commercial organic fertiliser $\left(\right.$ Evergrow $\left.^{\circ}\right)$ on growth, nitrogen use efficiency, yield, nutritional quality, and profitability of maize under greenhouse conditions. The treatments included: (1) sole application of BSFFF, conventional compost of brewers' spent grain (BSG), Evergrow, and NPK at rates equivalent to $100 \mathrm{~kg}$ nitrogen (N) per hectare; (2) BSFFF and BSG combined with NPK so that each fertiliser supplies $50 \%$ of the N required; and (3) the control (unamended soil). Our findings revealed that BSFFF increased maize grain yield at higher rates: 2-25, 25-113 and 153-212\% than NPK, BSG and Evergrow, respectively. Similarly, the BSF frass application led to higher maize growth and yield than the control treatment. The agronomic $\mathrm{N}$ use efficiency of maize grown using BSFFF was 2 and 3 times higher compared to that of BSG and Evergrow, respectively. Maize grown using BSFFF and NPK had higher crude protein and crude fibre content compared to the other treatments. The net income generated from the commercialisation of maize grown using a combination of BSFFF and NPK was 2, 163 and 173\% higher than those achieved using sole NPK, mixture of BSG and NPK, and sole BSFFF, respectively. Our results imply that developing and promoting BSFFF alone or in integration with NPK can enhance the food security and livelihoods of smallholders, while safeguarding planetary health.
\end{abstract}

Keywords: insect frass fertiliser, soil fertility, grain yield, grain nutrient quality, economic benefit

\section{Introduction}

The black soldier fly (BSF) (Hermetia illucens, L) is an efficient recycler of organic wastes into nutrient-rich organic fertiliser for crop production and soil health management (Beesigamukama et al., 2021; Lalander et al., 2015). Due to their high waste degradation efficiency (6578\%) (Diener et al., 2011; Li et al., 2011), the BSF larvae have been reported to shorten the compost maturity period to 5 weeks, compared to 8-24 weeks of conventional composting methods (Beesigamukama et al., 2020a, 2021). Furthermore, the BSF larvae can drastically reduce pathogens (Erickson et al., 2004; Klammsteiner et al., 2020; Lalander et al., 2015) and chemical contaminants (Lalander et al., 2016) contained in organic waste to levels permissible for field application of the resultant organic fertiliser product (Bernal et al., 2009).

The BSF frass can be integrated as fertiliser for production of crops such as maize (Zea mays L.), the most important crop worldwide (Jain, 2014; Sandhu et al., 2007) grown for food (Rouf et al., 2016; Shah et al., 2015), feed (Adiaha, 2016), pharmaceutical (Kumar and Narayan, 2013), herbal 
and fuel production (Abdulrahaman and Kolawole, 2006). In sub-Saharan Africa (SSA), maize is a strategic food security crop for more than 300 million Africans, grown on 25 million hectares (Badu-Apraku, 2017). However, maize's food security and economic contribution are challenged by poor soil fertility linked to nutrient depletion, limited fertiliser use, poor management of pests, climate change, and socioeconomic and institutional hurdles (AGRA, 2014; De Groote et al., 2010; Gibbon et al., 2007; Kassie et al., 2015; Stewart et al. 2020). Studies indicate that low soil fertility, low soil nitrogen, and drought reduce maize yields in Africa by 62,76 and $54 \%$, respectively (Gibbon et al., 2007). This is a huge loss given the number of food-insecure people in Africa, 332 million in 2016 (FAO et al., 2017). For optimal maize growth, nitrogen $(\mathrm{N})$ must be sufficient throughout the growing period because it plays a significant role in key physiological processes such as the synthesis of chloroplasts, proteins, amino acids, and cell division (Fageria, 2001). Inorganic fertilisers' adoption is low in SSA, mainly due to high prices and limited access to credit. Further, there is little use of organic fertilisers due to competing uses for feed and fuel (Ndambi et al., 2019). Therefore, an alternative source of fertiliser is crucial to enhance the resilience and food security of SSA. The insect frass obtained as a by-product of BSF larvae production can play a vital role in mitigating soil nutrient deficiency in SSA, thereby increasing agricultural productivity and food security.

Previous studies have demonstrated the potential of BSF frass for improving plant health, crop yield, and soil fertility (Alattar et al., 2016; Beesigamukama et al., 2020b,c; Green and Popa, 2012; Quilliam et al., 2020; Zahn, 2017). However, there is inadequate information on BSF frass fertiliser impact on the growth performance and nutritional status of maize. Furthermore, no information exist on their combination with mineral fertiliser (NPK) as well as economic impact on maize production. This study evaluated the comparative impact of: (1) sole application of black soldier fly frass fertiliser (BSFFF), conventional compost of brewers' spent grain (BSG), commercial organic fertiliser (Evergrow $\left.{ }^{\circ}\right)$, and NPK at rates equivalent to $100 \mathrm{~kg}$ nitrogen $(\mathrm{N})$ per hectare; (2) BSFFF and BSG combined with NPK so that each fertiliser supplies $50 \%$ of the $\mathrm{N}$ required; and (3) the control (unamended soil) on the: growth, nitrogen use efficiency, yield, nutritional quality, and profitability of maize under greenhouse conditions. This is relevant to generate the necessary information for integrating BSF frass fertiliser into the existing farming practices.

\section{Materials and methods}

\section{Experimental site}

A greenhouse experiment was carried out at the International Centre of Insect Physiology and Ecology (icipe) $\left(1^{\circ} 10^{\prime} 59^{\prime \prime} \mathrm{S}, 36^{\circ} 55^{\prime} 34^{\prime \prime} \mathrm{E}\right)$, Nairobi, Kenya. The soil used for crop production during experiments was collected from icipe at a depth of $0-20 \mathrm{~cm}$. The soil was classified as an Acric Ferralsol (Gachene and Kimaru, 2003) with loamy textural class, medium acidity, and low organic matter levels, total nitrogen, and available phosphorus. Before experiments, the soil was analysed for $\mathrm{pH}$, organic carbon, and nutrient concentrations using standard laboratory methods (Okalebo et al., 2002). Table 1 presents the soil analysis results.

\section{Source of fertilisers}

The study consisted of four fertilisers: BSFFF, a conventionally composted organic fertiliser, a commercial organic fertiliser (Evergrow), and mineral fertiliser (NPK 17:17:17). The Evergrow and NPK fertilisers were sourced from Sanergy Ltd and Kenya farmers' Association, respectively. The conventional compost was generated from BSG, while the BSF frass was obtained from BSF rearing at the animal rearing and quarantine unit at icipe. The two organic materials were composted following the procedures described below.

\section{Brewery spent grain and BSF frass composting}

The BSF larvae were reared on BSG following procedures described in Beesigamukama et al. (2021). After larval harvesting, the BSF frass generated was composted using the heap composting method to obtain a mature and stable organic fertiliser product, referred to as BSF frass fertiliser. Since the $\mathrm{C} / \mathrm{N}$ ratios of the BSG and BSF frass were below the value recommended for efficient composting, they were amended with rice husks to achieve $\mathrm{C} / \mathrm{N}$ of $25: 1$ (Inckel et al., 2005). The amount of rice husk required to adjust the $\mathrm{C} / \mathrm{N}$ ratio of BSG and BSF frass to $25: 1$ was calculated (Richard and Trautmann, 1996). Table 2 presents

\section{Table 1. Properties of the soil used during experiments.}

\begin{tabular}{|c|c|}
\hline Soil parameter & Value \\
\hline $\mathrm{pH}$ & 5.80 \\
\hline Total nitrogen (\%) & 0.05 \\
\hline Total organic carbon (\%) & 0.24 \\
\hline Available phosphorus (mg/kg) & 5.0 \\
\hline Potassium $(\mathrm{me} \%)^{1}$ & 0.84 \\
\hline Calcium (me\%) & 2.2 \\
\hline Magnesium (me\%) & 2.77 \\
\hline Manganese (me\%) & 0.43 \\
\hline Copper (mg/kg) & 1.00 \\
\hline Iron (mg/kg) & 29.5 \\
\hline Zinc (mg/kg) & 3.00 \\
\hline Sodium (me\%) & 0.28 \\
\hline
\end{tabular}

${ }^{1} \mathrm{me} \%=$ milliequivalent percentage. 
characteristics of raw composting substrates, composted BSF frass and BSG, and the commercial organic fertilisers.

\section{Treatments and experimental setup}

The BSFFF, BSG, Evergrow, and NPK fertiliser were applied at uniform rates equivalent to $100 \mathrm{~kg} \mathrm{~N} / \mathrm{ha}$ in two sets of experiments. In the first set of treatments, $100 \%$ of the $\mathrm{N}$ required was supplied using sole organic fertilisers and sole NPK. These were denoted as BSFFF, BSG, and Evergrow, NPK for sole BSFFF, BSG, Evergrow, and NPK, respectively. The quantity of fertilisers required to supply the $100 \mathrm{~kg} \mathrm{~N} /$ ha were equivalent to $2.8,4.1,10 \mathrm{t} /$ ha for sole BSFFF, BSG, Evergrow, respectively, and $588 \mathrm{~kg} /$ ha for sole NPK. In the second set of treatments, the BSFFF and BSG were combined with mineral fertiliser, whereby $50 \%$ of the $\mathrm{N}$ required was supplied using organic fertilisers, and the other $50 \%$ was supplied using mineral NPK fertiliser. These were denoted as BSFFF/NPK and BSG/NPK for combined BSFFF, BSG treatments, respectively. The quantity of fertilisers required to supply $50 \%$ of the $\mathrm{N}$ required (that is $50 \mathrm{~kg} \mathrm{~N} / \mathrm{ha}$ ) was equivalent to $1.4,2.05$ $\mathrm{t} / \mathrm{ha}$ for BSFFF and BSG, respectively, and $294 \mathrm{~kg} / \mathrm{ha}$ for NPK. In both experiments, the control treatment consisted of unamended soil.

The experiments were carried out in a greenhouse using polythene pots measuring $30 \mathrm{~cm}$ long, $40 \mathrm{~cm}$ wide, and $60 \mathrm{~cm}$ deep. Each polythene pot was filled with $10 \mathrm{~kg}$ of fresh soil, which was mixed with the different treatments. The experiments were arranged in a randomised complete block design with four replicates. Each replicate consisted of 10 pots, arranged at a spacing of $70 \times 30 \mathrm{~cm}$. Two seeds of maize variety $\mathrm{H} 517$ sourced from Kenya Seed Company were planted per pot. At two weeks after germination, thinning was done to maintain one plant per pot. The organic fertilisers (BSFFF, BSG, and Evergrow) were applied one week before sowing. The NPK fertiliser was applied in two splits, at sowing (50\%) and four weeks after planting (50\%). During experiments, weeds were controlled by hand pulling, while a drip irrigation system was installed to cater for crop water requirements.

\section{Maize growth, yield, and nutritional quality}

Six maize plants were randomly selected and tagged from each treatment for the determination of growth parameters. Data on plant height, stem diameter, number of leaves, and chlorophyll content were collected every four weeks, from the fourth week after sowing up to the maturity stage. Plant height was measured using a tape measure, from ground level to the tip of the shoot. Maize stem diameter was measured using a vernier caliper placed at the $10 \mathrm{~cm}$ mark from the ground level. The number of leaves per plant was determined by hand counting, while leaf chlorophyll concentration was measured using a SPAD meter placed on the fourth fully opened leaf from the top (Yuan et al., 2016).

Maize grain and stover yield data were collected at maturity by harvesting all plants per treatment. Plants were cut at ground level, and their ears threshed to determine grain weights and weight of residues using a weighing scale. Grain and stover samples were airdried to $12.5 \%$ moisture content to determine grain and residues yields per hectare $(\mathrm{t} / \mathrm{ha})$. The grain yield from each treatment was used to calculate the economic yield produced per unit amount of nitrogen supplied from each treatment, using the agronomic nitrogen efficiency $\left(\mathrm{AE}_{\mathrm{N}}\right)$ (Equation 1) (Baligar et al., 2001).

Table 2. Characteristics of raw substrates, composted black soldier fly (BSF) frass and brewery spent grain (BSG), and the commercial organic fertiliser (Evergrow) used in experiments.

-

Parameter

$\mathrm{pH}$

Organic carbon (\%)

Nitrogen (\%)

Phosphorus (\%)

Potassium (\%)

Calcium (\%)

Magnesium (\%)

Iron (\%)

Copper (mg/kg)

Manganese $(\mathrm{mg} / \mathrm{kg})$

Zinc ( $\mathrm{mg} / \mathrm{kg}$ )

$\mathrm{C} / \mathrm{N}$ ratio
Composting substrates

Raw frass Raw BSG Rice husks

Mature and stable composts

Composted BSF frass Composted BSG

7.3

38.6

3.6

0.50

0.29

0.97

0.10

0.031

25.0

109.0

182.0

10.7
7.1

37.9

2.5

0.37

0.24

0.28

0.15

0.019

15.0

262.0

167.0

15.5
Evergrow fertiliser

7.8

20

1.0

0.4

0.5

1.3

0.2

0.12

100

200

850

20 
$A E_{N}(\mathrm{~kg} / \mathrm{kg} \mathrm{N})=\frac{\left[\operatorname{Grain}_{\text {yield }}(\mathrm{kg} / \mathrm{ha})-\text { Grain yield }_{C}(\mathrm{~kg} / \mathrm{ha})\right]}{\text { Quantity of } N \text { applied }(\mathrm{kg} \mathrm{N} / \mathrm{ha})}$

where,

$F$ represents fertiliser treatment

$C$ represents the control

Part of the air-dried grain samples was ground using an analytical mill to analyse for crude protein, crude fibre, carbohydrates using standard laboratory methods, while the energy and ash content were calculated (AOAC, 1990).

\section{Economic analysis}

Gross margin (Equation 2), benefit-cost ratio (BCR) (Equation 3), and return on investment (Equation 4) were computed to determine the economic performance of BSF frass fertiliser (Onsongo et al., 2018). Price data for fertilisers and maize seed were obtained from Africa fertiliser (Africa Fertilizer, 2019) and Kenya farmers' association, respectively. Labour expenses (land preparation, planting, weeding and harvesting) were calculated by recording the time taken to perform each activity and valuing labour at the rate of 1.25 USD per hour (Kenyan Government, 2019). The price of maize grain was obtained from human data exchange (https://data.humdata.org). Since stover is used as an animal feed in Kenya, it was valued at 22.1 USD per tonne (Mucheru-Muna et al., 2014).

$$
\begin{aligned}
& \text { Gross margin }(\%)=\frac{\text { Net income }}{\text { Gross income }} \times 100 \\
& \text { Benefit to cost ratio }=\frac{\text { Net income }}{\text { Total variable costs }} \\
& \text { Return on investment }=\frac{\text { Net income }}{\text { Total variable costs }} \times 100
\end{aligned}
$$

where,

\section{Net income $=$ Gross income - Total variable costs}

Total variable costs include cost of fertilisers and maize seeds, and labour expenses from land preparation to harvesting.

\section{Data analysis}

Data were checked for normality using the ShapiroWilk test. Data on plant height, number of leaves, stem diameter, chlorophyll concentration was analysed using a linear mixed-effect model with 'lmer' function from the package 'lme4' in R statistical software with fertiliser treatment and sampling time as fixed effects, and replication as random effect. Analysis of variances was performed on maize grain and stover yields and agronomic nitrogen use efficiency. Computation of least squares means was done using 'lsmeans' package. Significant means were compared using the Student Newman Keuls Test at $P \leq 0.05$. All the statistical analyses were conducted using $\mathrm{R}$ software version 3.6.0 (R Core Team, 2019).

\section{Results}

\section{Maize plant height, leaf growth, and stem diameter}

The different fertiliser treatments caused significant $(P<0.001)$ differences in plant height during experiments. At four weeks, the plant height ranged between 23 and $54 \mathrm{~cm}$, from where it increased significantly up to 12 weeks. Thereafter, the plant height increased slightly to reach peak values $(66-197 \mathrm{~cm})$ at 16 weeks. Maize grown using fertiliser treatments was significantly taller than maize grown using the control treatment throughout the experiments. Pots treated with BSFFF produced significantly taller maize plants than pots amended using Evergrow and BSG compost. Likewise, maize grown using BSFFF/NPK was significantly taller than that grown in soil amended with NPK and BSGNPK treatments at 12 and 16 weeks after planting. Pots amended with BSFFF/NPK produced the tallest maize plants $(197 \mathrm{~cm}), 11,17,48,88 \%$ taller than those grown using NPK, BSG/NPK, BSG and Evergrow fertilisers, respectively (Table 3 ).

There were significant differences $(P<0.001)$ in the number of leaves of maize plants treated with different fertiliser treatments (Table 3). Pots treated with fertiliser treatments produced maize with a higher number of leaves than those grown using the control treatment. Maize grown using BSFFF/NPK produced a significantly higher number of leaves than maize grown using other fertiliser treatments at 8,12 , and 16 weeks after planting. Likewise, pots treated with BSG/NPK produced maize plants with a significantly higher number of leaves than those amended with BSG compost and Evergrow at 8,12, and 16 weeks after planting (Table 3).

The maize stem diameter was also observed to vary significantly $(P<0.001)$ due to different fertiliser amendments (Table 3 ). The maize stem diameter followed an increasing trend throughout the study, with minimal changes observed at 16 weeks after planting. All fertiliser treated pots produced maize plants with significantly bigger stem diameters than the control treatment. At four and eight weeks, maize grown in pots amended with a BSFFF/NPK had significantly bigger stem diameter than that produced using the control, BSG and Evergrow treatments. Similarly, use of BSFFF/NPK produced maize with significantly bigger stem diameters than at 10 and 12 weeks after planting. The biggest stem diameter $(29.5 \mathrm{~mm})$ was recorded at 16 weeks after planting from maize grown using BSFFF/NPK, and this was $11,55,27$, and $18 \%$ higher than those achieved using NPK, Evergrow, BSG, and BSG/NPK, respectively (Table 3). 
Table 3. Effect of various fertiliser types on maize plant height, leaf growth, and stem diameter. ${ }^{1}$

\begin{tabular}{|c|c|c|c|c|c|}
\hline Parameter & Treatment & Week 4 & Week 8 & Week 12 & Week 16 \\
\hline \multirow[t]{8}{*}{ Height (cm) } & BSFFF & $54.1 \pm 2.95 a$ & $109.4 \pm 3.85 a$ & $170.3 \pm 4.89 b$ & $177.3 \pm 5.51 b$ \\
\hline & BSG & $41.5 \pm 1.98 b$ & $83.0 \pm 2.77 \mathrm{~b}$ & $130.7 \pm 7.31 \mathrm{c}$ & $133.4 \pm 7.75 c$ \\
\hline & NPK & $49.6 \pm 4.20 \mathrm{ab}$ & $103.1 \pm 7.66 \mathrm{a}$ & $171.9 \pm 7.22 \mathrm{~b}$ & $178.5 \pm 6.26 b$ \\
\hline & Evergrow & $41.7 \pm 0.64 b$ & $68.3 \pm 1.74 \mathrm{c}$ & $98.8 \pm 4.84 d$ & $104.7 \pm 4.73 d$ \\
\hline & BSFFF/NPK & $49.1 \pm 1.32 \mathrm{ab}$ & $108.3 \pm 4.06 \mathrm{a}$ & $192.6 \pm 4.98 \mathrm{a}$ & $197.3 \pm 5.13 a$ \\
\hline & BSG/NPK & $49.5 \pm 2.04 a b$ & $102.7 \pm 4.17 a$ & $164.6 \pm 5.40 \mathrm{~b}$ & $169.3 \pm 6.06 b$ \\
\hline & Control & $23.2 \pm 1.21 \mathrm{c}$ & $44.7 \pm 1.63 d$ & $64.0 \pm 3.37 \mathrm{e}$ & $65.7 \pm 3.32 \mathrm{e}$ \\
\hline & $P$-value & $<0.001$ & $<0.001$ & $<0.001$ & $<0.001$ \\
\hline \multirow[t]{8}{*}{ Number of leaves } & BSFFF & $8.0 \pm 0.31 a$ & $10.5 \pm 0.24 b$ & $12.4 \pm 0.17 \mathrm{~b}$ & $13.9 \pm 0.14 b$ \\
\hline & BSG & $6.7 \pm 0.48 \mathrm{a}$ & $8.7 \pm 0.25 c$ & $10.6 \pm 0.30 c$ & $11.3 \pm 0.39 c$ \\
\hline & NPK & $7.6 \pm 0.42 a$ & $10.8 \pm 0.32 b$ & $12.7 \pm 0.33 b$ & $13.7 \pm 0.40 \mathrm{~b}$ \\
\hline & Evergrow & $7.4 \pm 0.24 a$ & $8.2 \pm 0.20 c$ & $10.1 \pm 0.31 \mathrm{c}$ & $11.1 \pm 0.41 \mathrm{c}$ \\
\hline & BSFFF/NPK & $7.4 \pm 0.16 \mathrm{a}$ & $11.8 \pm 0.13 a$ & $13.8 \pm 0.18 \mathrm{a}$ & $14.8 \pm 0.09 a$ \\
\hline & BSG/NPK & $7.5 \pm 0.22 a$ & $10.3 \pm 0.21 b$ & $12.2 \pm 0.23 b$ & $13.3 \pm 0.15 b$ \\
\hline & Control & $5.7 \pm 0.36 b$ & $6.3 \pm 0.39 d$ & $7.9 \pm 0.13 d$ & $8.5 \pm 0.19 d$ \\
\hline & $P$-value & 0.001 & $<0.001$ & $<0.001$ & $<0.001$ \\
\hline \multirow[t]{8}{*}{ Stem diameter (mm) } & BSFFF & $15.3 \pm 0.96 a$ & $24.8 \pm 0.37 a$ & $26.1 \pm 0.12 b$ & $27.6 \pm 0.20 \mathrm{~b}$ \\
\hline & BSG & $10.5 \pm 0.52 b$ & $19.7 \pm 1.05 b$ & $22.3 \pm 0.92 c$ & $23.2 \pm 0.97 d$ \\
\hline & NPK & $13.2 \pm 1.14 a$ & $23.1 \pm 1.53 a b$ & $25.9 \pm 0.36 b$ & $26.5 \pm 0.30 \mathrm{bc}$ \\
\hline & Evergrow & $10.5 \pm 0.60 \mathrm{~b}$ & $14.8 \pm 0.73 c$ & $18.4 \pm 0.78 d$ & $19.1 \pm 0.76 \mathrm{e}$ \\
\hline & BSFFF/NPK & $14.1 \pm 0.75 a$ & $25.6 \pm 1.30 \mathrm{a}$ & $28.0 \pm 1.05 a$ & $29.5 \pm 0.90 \mathrm{a}$ \\
\hline & BSG/NPK & $12.9 \pm 0.57 a$ & $23.2 \pm 0.64 a b$ & $24.4 \pm 0.19 b$ & $25.0 \pm 0.32 b c$ \\
\hline & Control & $4.9 \pm 0.21 \mathrm{c}$ & $7.9 \pm 0.94 d$ & $9.2 \pm 0.32 \mathrm{e}$ & $9.7 \pm 0.19 f$ \\
\hline & $P$-value & $<0.001$ & $<0.001$ & $<0.001$ & $<0.001$ \\
\hline
\end{tabular}

\section{Chlorophyll concentration}

The maize leaf chlorophyll concentration was significantly $(P<0.001)$ influenced by the different fertiliser treatments (Figure 1). The leaf chlorophyll concentrations of maize grown using fertiliser treatments significantly increased to peak levels (32-49 SPAD values) at eight weeks after planting and decreased afterward, except for Evergrow treatment, which reached peak values at 16 weeks after planting. Maize grown in pots treated with BSF NPK had significantly higher leaf chlorophyll concentrations than other treatments, except Evergrow at 16 weeks after planting (Figure 1).

All fertiliser treated pots produced maize with significantly higher leaf chlorophyll concentrations than the control treatment from the eighth week of experiments (Figure 1). The highest leaf chlorophyll concentration was achieved at eight weeks after planting from maize grown using BSFFF/ NPK, and this was 22, 25, 26, 46, and 53\% higher than those of maize grown using NPK, BSG/NPK, BSFFF, Evergrow, and BSG, respectively. Similarly, the leaf chlorophyll concentration of maize grown using BSFFF/NPK was significantly higher than those of other treatments by $23-88 \%$ at 16 weeks after planting, except where Evergrow fertiliser was applied (Table 1).

\section{Maize grain and stover yields}

The different fertiliser amendments caused significant $(P<0.001)$ differences in maize grain yield (Figure 2$)$. Fertiliser application increased maize grain yield by $46-$ $111 \%$ higher than the control treatment. The highest grain yield (7.98 $\mathrm{t} / \mathrm{ha}$ ) was produced from maize grown in pots treated with BSFFF/NPK, and this was $23-68 \%$ higher than the grain yields achieved using other fertiliser treatments. Maize grain yields from pots treated with BSFFF, NPK, and BSG/NPK were significantly higher than those produced using Evergrow and sole BSG compost. Furthermore, the grain yield from maize grown in pots treated with BSFFF was 73 and 153\% higher than those produced using BSG and Evergrow fertiliser, respectively.

The maize stover yield also varied significantly $(P<0.001)$ due to different fertiliser treatments. Maize grown using 


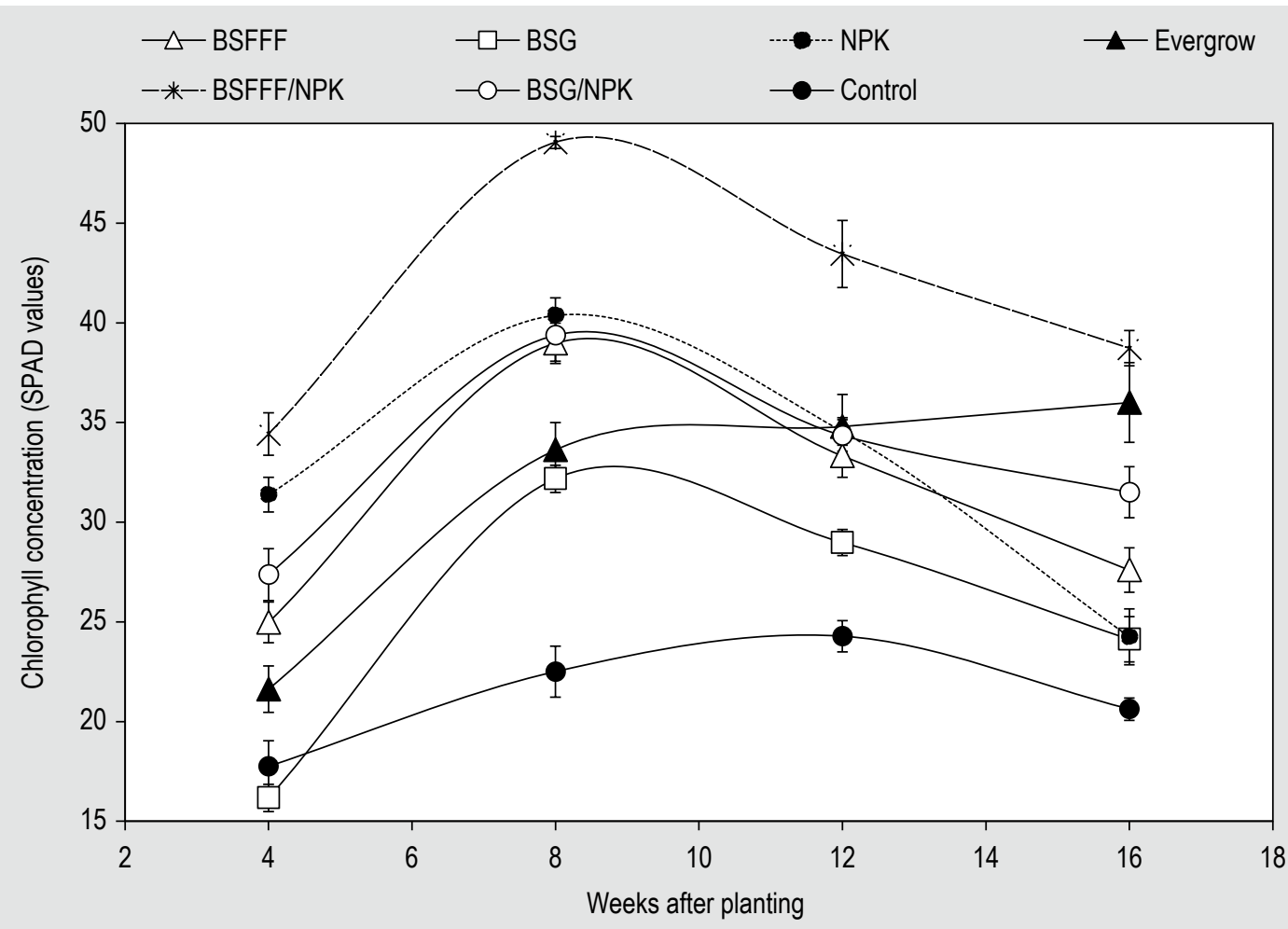

Figure 1. Effect of various fertiliser types on maize leaf chlorophyll concentration. BSFFF = black soldier fly frass fertiliser; BSFFF/ NPK = black soldier fly frass fertiliser and NPK; BSG = brewery spent grain compost; BSG/NPK = brewery spent grain compost and NPK; control = unamended soil; Evergrow = commercial organic fertiliser; NPK = mineral fertiliser.

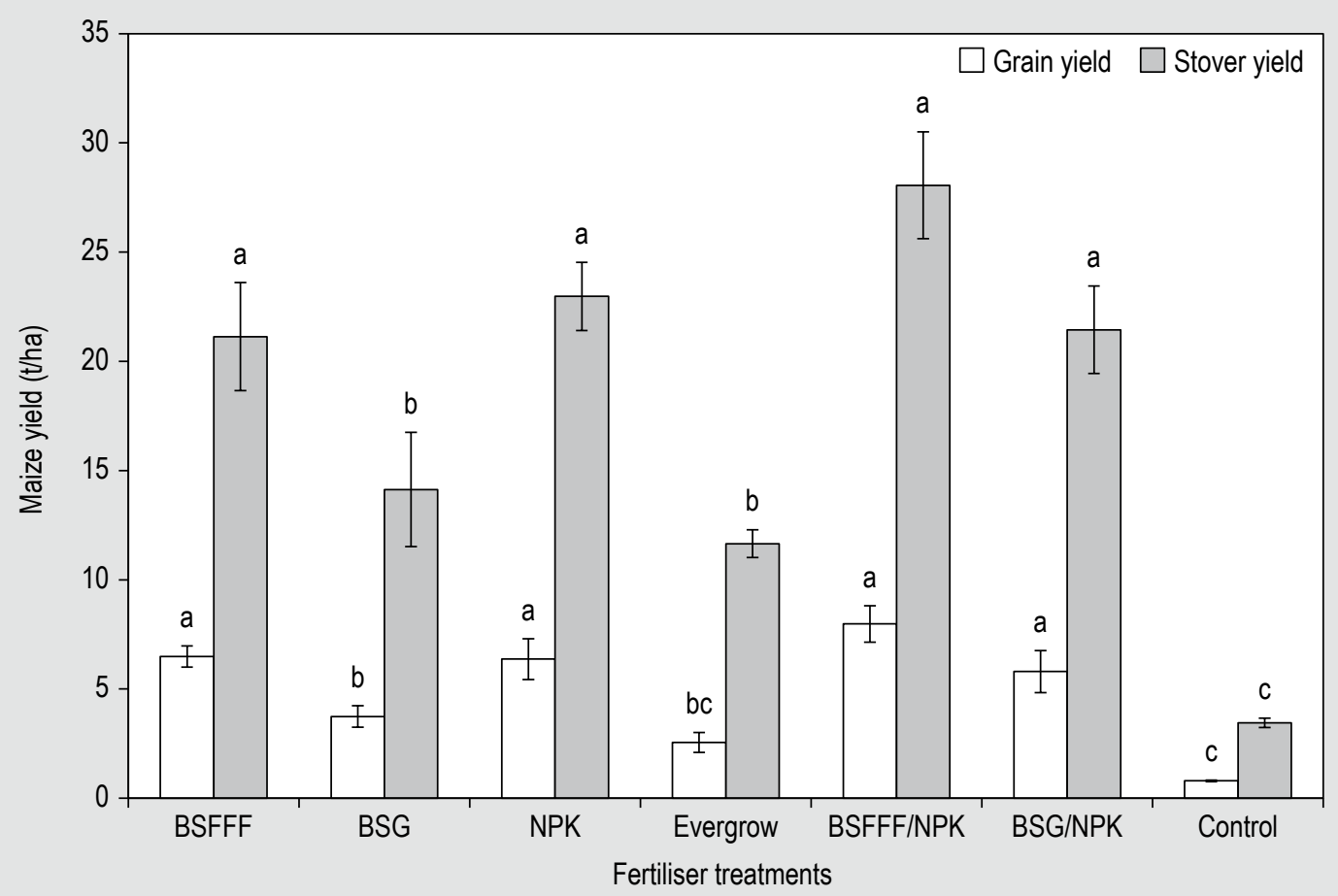

Figure 2. Effect of various fertiliser types on maize grain and stover yields. BSFFF = black soldier fly frass fertiliser; BSFFF/NPK = black soldier fly frass fertiliser and NPK; BSG = brewery spent grain compost; BSG/NPK = brewery spent grain compost and NPK; control = unamended soil; Evergrow $=$ commercial organic fertiliser; NPK = mineral fertiliser. Means followed by the same letters are not significantly different at $P \leq 0.05$. 
BSFFF, NPK, and BSG/NPK produced significantly higher stover yields than the maize produced using BSG and Evergrow. All fertiliser treated pots produced significantly higher maize stover yield than the control treatment (Figure 2).

\section{Agronomic nitrogen use efficiency and economic returns}

The different fertiliser treatments caused significant $(P<0.001)$ variations in the maize $\mathrm{AE}_{\mathrm{N}}$ (Figure 3$)$. The $\mathrm{AE}_{\mathrm{N}}$ of maize grown using BSFFF/NPK was significantly higher than those of maize grown using the BSG and Evergrow, by 2.1 and 3.1 times, respectively. Likewise, the $\mathrm{AE}_{\mathrm{N}}$ of maize grown using BSFFF, NPK, and BSG/NPK were significantly higher than that of maize harvested from plots amended with Evergrow by 153, 149, and 127\%, respectively. Maize grown using BSFFF/NPK achieved the highest $\mathrm{AE}_{\mathrm{N}}(79.8$ $\mathrm{kg} / \mathrm{kg} \mathrm{N}$ ), which was 23, 25, and 38\% higher than those achieved using BSFFF, NPK, and BSG/NPK, respectively. On the other hand, the lowest maize $\mathrm{AE}_{\mathrm{N}}(25.6 \mathrm{~kg} / \mathrm{kg} \mathrm{N})$ was recorded in maize grown using Evergrow fertiliser (Figure 3).

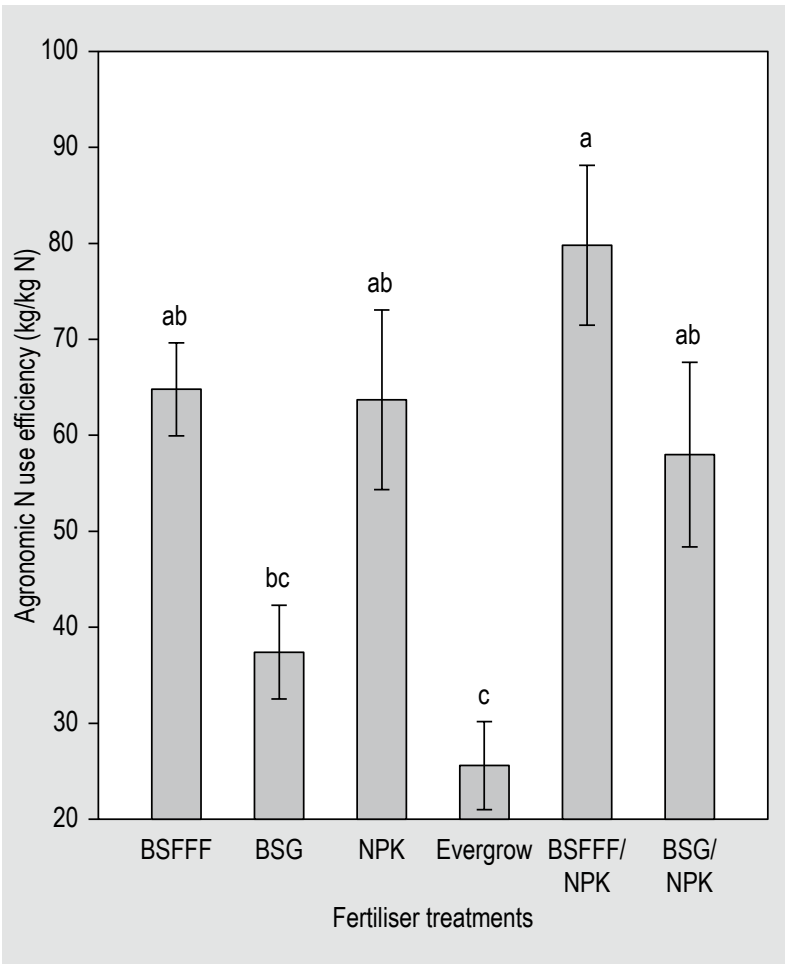

Figure 3. Agronomic nitrogen use efficiency of maize grown using various fertiliser types. BSFFF = black soldier fly frass fertiliser; BSFFF/NPK = black soldier fly frass fertiliser and NPK; BSG = brewery spent grain compost; BSG/NPK = brewery spent grain compost and NPK; Evergrow = commercial organic fertiliser; NPK = mineral fertiliser. Means followed by the same letters are not significantly different at $P \leq 0.05$.
The economic returns from maize produced using different fertiliser treatments are presented in Table 4. Maize grown using BSFFF/NPK fertilisers generated the highest net income, which was 2,163, and 173\% higher than those achieved using NPK, BSG/NPK, and BSFFF, respectively. The highest gross margin, $\mathrm{BCR}$, and return on investment were achieved from maize grown using NPK, followed by maize harvested from pots amended with BSFFF/NPK.

However, maize grown using Evergrow, BSG, and the control treatments yielded negative values of net income, gross margin, benefit-cost ratio and return on investment (Table 4)

\section{Maize nutritional quality}

There were significant differences $(P<0.001)$ in the crude protein levels of maize grown using different fertiliser treatments (Table 5). All fertiliser treatments produced maize with significantly higher (20-75\%) crude protein content than the control. Grain harvested from maize grown using BSFFF/NPK fertilisers achieved the highest crude protein content, which was significantly higher than those of maize grown using other treatments. The crude protein content of maize grown using BSFFF was significantly higher than those of maize grown using BSG, Evergrow, and BSG/NPK by 31,29 , and 10\%, respectively (Table 5).

The crude fat content of maize also varied significantly $(P<0.001)$ due to different fertiliser amendments (Table 5). The crude fat contents of maize grown using BSG and Evergrow and control were significantly higher than those of other fertiliser treatments, except where NPK was applied. Maize grown in pots amended with BSG achieved the highest crude fat content, while the pots treated with BSFFF produced maize with the lowest crude fat content. There were significant $(P<0.001)$ differences in the crude fibre content of maize grown using different fertiliser amendments (Table 5).

All fertiliser treatments produced maize with significantly higher crude fat content than control. Maize grown using BSFFF/NPK, Evergrow, and BSG/NPK achieved significantly higher crude fat levels than the fertiliser treatments, except NPK (Table 5). The control treatment produced maize grains with significantly higher ash content than all fertiliser treatments (Table 5). Maize grown using BSFFF and BSG/ NPK had the highest ash contents among the fertiliser treatments. In contrast, pots amended with Evergrow and BSFFF/NPK produced maize with the least ash contents (Table 5).

The carbohydrate content and energy levels of maize grown using different fertilisers also varied significantly $(P<0.001)$. The control treatment produced maize grains with significantly higher carbohydrates content than other 
Table 4. Net income and gross margin generated from maize produced using various fertiliser types. ${ }^{1}$

\begin{tabular}{|c|c|c|c|c|}
\hline Fertiliser treatment & Net income (US dollar) & Gross margin (\%) & Benefit-cost ratio & Return on investment (\%) \\
\hline BSFFF & 789.6 & 26.5 & 0.38 & 38.4 \\
\hline BSG & $-1,150.9$ & -71.9 & -0.41 & -40.6 \\
\hline NPK & $2,116.8$ & 73.3 & 2.91 & 290.5 \\
\hline Evergrow & $-5,180.7$ & -467.1 & -0.81 & -81.3 \\
\hline BSFFF/NPK & $2,156.8$ & 59.9 & 1.55 & 154.9 \\
\hline BSG/NPK & 818.7 & 27.4 & 0.46 & 45.9 \\
\hline Control & -7.6 & -2.3 & -0.02 & -2.0 \\
\hline
\end{tabular}

Table 5. Nutritional value of grain from maize grown using various fertiliser types. ${ }^{1}$

\begin{tabular}{lllllll} 
Fertiliser treatment & Crude protein (\%) & Crude fat (\%) & Crude fibre (\%) & Ash content (\%) & Carbohydrates (\%) & Energy (kcal/100 g) \\
BSFFF & $8.0 \pm 0.29 \mathrm{~b}$ & $4.2 \pm 0.31 \mathrm{c}$ & $2.7 \pm 0.13 \mathrm{~b}$ & $1.3 \pm 0.07 \mathrm{~b}$ & $74.2 \pm 0.85 \mathrm{bc}$ & $375.7 \pm 2.01 \mathrm{~b}$ \\
BSG & $6.1 \pm 0.32 \mathrm{c}$ & $6.8 \pm 0.24 \mathrm{a}$ & $2.5 \pm 0.13 \mathrm{~b}$ & $1.2 \pm 0.07 \mathrm{~b}$ & $73.6 \pm 0.59 \mathrm{bc}$ & $390.2 \pm 1.95 \mathrm{a}$ \\
NPK & $7.6 \pm 0.2 \mathrm{~b}$ & $5.2 \pm 0.1 \mathrm{bc}$ & $3.0 \pm 0.11 \mathrm{a}$ & $1.1 \pm 0.05 \mathrm{~b}$ & $73.2 \pm 0.39 \mathrm{bc}$ & $379.1 \pm 1.47 \mathrm{~b}$ \\
Evergrow & $6.2 \pm 0.41 \mathrm{c}$ & $5.7 \pm 0.5 \mathrm{ab}$ & $2.7 \pm 0.06 \mathrm{ab}$ & $1.0 \pm 0.04 \mathrm{~b}$ & $75.3 \pm 0.77 \mathrm{ab}$ & $387.2 \pm 2.61 \mathrm{a}$ \\
BSFFF/NPK & $8.9 \pm 0.28 \mathrm{a}$ & $4.2 \pm 0.21 \mathrm{c}$ & $3.3 \pm 0.16 \mathrm{a}$ & $1.0 \pm 0.04 \mathrm{~b}$ & $72.4 \pm 0.17 \mathrm{c}$ & $372.1 \pm 2.03 \mathrm{~b}$ \\
BSG/NPK & $7.3 \pm 0.24 \mathrm{~b}$ & $4.5 \pm 0.35 \mathrm{c}$ & $3.2 \pm 0.12 \mathrm{a}$ & $1.3 \pm 0.08 \mathrm{~b}$ & $73.4 \pm 0.82 \mathrm{bc}$ & $372.4 \pm 2.4 \mathrm{~b}$ \\
Control & $5.1 \pm 0.21 \mathrm{~d}$ & $6.3 \pm 0.32 \mathrm{a}$ & $2.1 \pm 0.1 \mathrm{c}$ & $1.5 \pm 0.05 \mathrm{a}$ & $76.7 \pm 0.23 \mathrm{a}$ & $393.7 \pm 2.31 \mathrm{a}$ \\
\hline
\end{tabular}

${ }^{1}$ BSFFF = black soldier fly frass fertiliser; BSFFF/NPK = black soldier fly frass fertiliser and NPK; BSG = brewery spent grain compost; BSG/NPK = brewery spent grain compost and NPK; control = unamended soil; Evergrow = commercial organic fertiliser; NPK = mineral fertiliser. Within the same column, means $( \pm$ standard error) followed by the same letter are not significantly different at $P \leq 0.05$.

treatments, except Evergrow. On the other hand, maize harvested from the control pots, and pots amended with Evergrow and BSG had significantly higher energy levels than those of maize grown using other treatments (Table 5).

\section{Discussion}

\section{Effect of various fertiliser types on maize growth and yield}

The BSF larval-based waste management technologies are crucial in converting the huge quantities of nutrients contained in waste streams into nutrient-rich larval biomass for incorporation as alternative protein additive in animal feeds, and high quality organic frass fertiliser for crop production. The integration of frass fertiliser into cropping practices would help to return nutrients back into the soil and increase farm productivity through reduced expenses on animal feed and fertiliser inputs. The nonsignificant differences in maize yield and $\mathrm{AE}_{\mathrm{N}}$ observed between BSFFF and NPK treatments indicate that the BSF frass fertiliser can perform as good as most commercial mineral fertilisers available in the market as previously reported by Beesigamukama et al. (2020c). This study's findings are crucial in changing attitudes towards organic fertiliser use, with the advantage of less bulkiness and high nutrient concentrations associated with high-quality organic fertilisers such as the BSF frass fertiliser. However, a tendency in higher maize grain yield and agronomic nitrogen use efficiency achieved using a combination of NPK and BSF frass fertilisers compared to sole NPK highlight the key role of organic fertilisers in integrated soil fertility management, especially improving nutrient availability and soil moisture retention (Geng et al., 2019; Nsoanya and Nweke, 2015; Quansah, 2010; Vanlauwe et al., 2015).

The higher maize growth and grain yields associated with all fertiliser treatments compared to the control (unamended soil) treatment are in line with previous studies (Gachimbi et al., 2005; Muchena et al., 2005; Tully et al., 2015), which have highlighted low soil fertility as one of the major factors limiting crop production in most SSA regions. Table 1 shows that the experimental soil was deficient in major nutrients required for maize production. Therefore, the use of quality fertiliser such as the BSF frass fertiliser could be an entry point for improving maize production, as demonstrated by 
the higher maize yield achieved (Figure 2). Our findings align with Beesigamukama et al. (2020c) and Quilliam et al. (2020), who reported higher growth, yield, and agronomic nitrogen use efficiency of maize grown in plots treated with BSF frass fertiliser due to the high $\mathrm{N}$ mineralisation and nutrient release rates (Adin Yéton et al., 2019).

The higher nutrient concentrations and lower $\mathrm{C} / \mathrm{N}$ ratio associated with BSF composted organic fertiliser (Table 2) highlight the high efficiency of BSF larvae in nutrient recycling, which has been previously reported (Beesigamukama et al., 2021; Lalander et al., 2015). Organic fertilisers with lower $\mathrm{C} / \mathrm{N}$ ratios, such as the BSF frass fertiliser are associated with faster nutrient release for crop production, and vice versa (Palomba, 2016). The higher maize chlorophyll concentration observed using BSFFF and BSFFF/NPK indicates the higher photosynthetic activity and nitrogen accumulation arising from the synergistic effect of combining fertilisers than using sole organic or sole mineral fertilisers (Figure 1). Nitrogen is essential in photosynthesis, cell division, protein formation, and vegetative growth (Kogbe and Adediran, 2003), which could have contributed to the better maize growth, yield, and agronomic nitrogen use efficiency of maize grown using the BSF frass fertiliser.

The observations described above are in line with the report by Beesigamukama et al. (2020b,c) and Kagata and Ohgushi (2012), who demonstrated that frass fertiliser is capable of improving soil nutrient availability, plant growth, and yield. Although not demonstrated in this study, the use of insect frass fertiliser has additional benefits for crop production, such as improved drought and salt tolerance, and disease suppression (Choi and Hassanzadeh, 2019; Houben et al., 2020). Furthermore, deeper plant root growth and spread due to plant growth-promoting organisms and growth hormones, such as auxin and gibberellins, have been reported while using insect frass as a biofertiliser (Poveda et al., 2019). Such behaviour of root growth could have been crucial in the nutrient acquisition by maize grown using BSF frass fertiliser, and consequently, the higher grain yield. The higher values of maize growth and yield achieved in treatments that received NPK alone compared to sole Evergrow, and BSG compost could be attributed to the higher nutrient availability associated with mineral fertilisers (Adebayo, 2017; Ojo et al., 2014).

\section{Nutritional quality and economic returns from maize grown using various fertiliser types}

The higher crude protein contents of maize grown using BSF frass fertiliser compared to the commercial fertilisers could be attributed to higher nutrient uptake, as reported previously (Beesigamukama et al., 2020b,c). This is because nitrogen is an integral part of amino acids. On the other hand, insect frass fertilisers are associated with better mineral nutrition, hence the higher crude protein in maize grown in pots amended with BSF frass fertiliser (Houben et al., 2020). The higher grain yield and nutritional quality of maize grown using BSF frass fertiliser indicate the role this product could play in improving food and nutrition security among the vulnerable segments particularly women and children in the rapidly growing populations in most developing countries. Therefore, the development of inclusive business models involving BSFFF as additional value-added product from insect farming would significantly contribute to solving socioeconomic and environmental problems in developing countries, aligning with the United Nations' Sustainable Development Goals 1, 2, 5, 6, 8, 9, 11, 12 and 15. With low initial capital investments, smallholder insect farmers have good opportunities to increase productivity, improve their livelihood and contribute to food security and a circular economy.

The negative values of net income recorded in maize grown using sole BSG compost and sole Evergrow indicate the poor quality yet expensive organic fertilisers used in most cropping systems of low- and middle-income countries. This could greatly decrease farm productivity. On the other hand, the higher net income achieved using BSF frass fertiliser compared to the conventional and commercial organic fertilisers indicates the high potential of insect frass fertiliser for increasing crop productivity. Furthermore, the increase in net income attained using a combination of BSF frass and NPK fertilisers compared to sole NPK highlights the role of frass fertiliser in increasing the profitability of maize production while reducing the high fertiliser costs associated with mineral fertiliser (Adamtey et al., 2016; Gram et al., 2020; Vanlauwe et al., 2015). Consequently, the adoption of high-quality and affordable organic fertilisers such as the BSF frass fertiliser could sustainably increase farm productivity (Ndambi et al., 2019; Rufino et al., 2007) and lift farmers out of poverty. The frass fertiliser can also be sold directly, thus increasing the household income of insect farmers. Therefore, BSF farming has potential to create jobs for the women and youths involved in the insect production chain, while conserving the environment by using the BSF larvae as biowaste converters (Chia et al., 2019).

\section{Conclusion}

The current study has revealed for the first time that the high fertiliser value of composted black soldier fly frass and its integration with mineral NPK fertiliser could be a solution for improved soil health and sustainable production of maize. The higher economic returns and nutritional quality of maize achieved using the BSF frass fertiliser indicate great potential for increasing household income, food, and nutrition security of smallholder farmers in lowand middle-income countries. Therefore, the BSF frass 
fertiliser should be considered an affordable and sustainable source of nutrients for improving soil fertility and crop yield. This study paves a pathway to cleaner production technologies by using the BSF larvae to recycle nutrients in organic waste into high-value insect-protein for livestock feeding and nutrient-rich organic fertiliser for improved soil health and crop productivity. Nevertheless, on-farm research is required to validate the current findings for large scale frass fertiliser application in Africa and beyond.

\section{Acknowledgements}

This research was financially supported by the Norwegian Agency for Development Cooperation, the Section for research, innovation, and higher education grant number RAF-3058 KEN-18/0005 (CAP-Africa), Canadian International Development Research Centre (IDRC) and the Australian Centre for International Agricultural Research (ACIAR) (INSFEED-Phase 2: Cultivate Grant No: 108866-001), the Netherlands Organization for Scientific Research, WOTRO Science for Global Development (NWO-WOTRO) (ILIPA-W 08.250.202), and The Rockefeller Foundation (SiPFeed-2018 FOD 009) through the International Centre of Insect Physiology and Ecology (icipe). We also gratefully acknowledge the support of the icipe core funders such as the United Kingdom's Foreign, Commonwealth \& Development Office (FCDO); the Swedish International Development Cooperation Agency (Sida); the Swiss Agency for Development and Cooperation (SDC); the Federal Democratic Republic of Ethiopia; and the Government of the Republic of Kenya. The views expressed herein do not necessarily reflect the official opinion of the donors.

\section{Conflict of interest}

The authors declare no conflict of interest.

\section{References}

Abdulrahaman, A.A. and Kolawole, O.M., 2006. Traditional preparations and uses of maize in Nigeria. Ethnobotanical Leaflets 10: 219-227.

Adamtey, N., Musyoka, M.W., Zundel, C., Cobo, J.G., Karanja, E., Fiaboe, K.K.M., Muriuki, A., Mucheru-Muna, M., Vanlauwe, B., Berset, E., Messmer, M.M., Gattinger, A., Bhullar, G.S., Cadisch, G., Fliessbach, A., Mäder, P., Niggli, U. and Foster, D., 2016. Productivity, profitability and partial nutrient balance in maize-based conventional and organic farming systems in Kenya. Agriculture, Ecosystems and Environment 235: 61-79. https://doi. org/10.1016/j.agee.2016.10.001

Adebayo, O.A., 2017. Growth and nutrient uptake of maize (Zea mays L.) amended with compost-enriched palm kernel cake growth and nutrient uptake of maize (Zea mays L.) amended with compostenriched palm kernel cake. Ibadan Journal of Agricultural Research 12: 23-32.
Adiaha, M.S., 2016. Influence of mineral fertilizer on the growth of maize (Zea mays L.) and soil fertility improvement for food security, environmental development and sustainable agriculture. World Scientific News 56: 189-216.

Bloukounon-Goubalan, A.Y., Saïdou, A., Obognon, N., Amadji, G., Lucien, I., Attanda, M., Clottey, V.A., Chrysostome, C.A.A.M., Kenis, M. and Mensah, G.A., 2019. Decomposition and nutrient release pattern of agro-processing by-products biodegraded by fly larvae in Acrisols. Archives of Agronomy and Soil Science 65: 1610-1621. https://doi.org/10.1080/03650340.2019.1572118

Africa Fertilizer, 2019. National fertilizer prices. Available at: https:// africafertilizer.org/national/ \#tab-id-3

Alliance for a Green Revolution in Africa (AGRA), 2014. Africa agriculture status report: climate change and smallholder agriculture in sub-Saharan Africa. AGRA, Nairobi, Kenya. Available at: https:// hdl.handle.net/10568/42343

Alattar, M., Alattar, F. and Popa, R., 2016. Effects of microaerobic fermentation and black soldier fly larvae food scrap processing residues on the growth of corn plants (Zea mays). Plant Science Today 3: 57-62. https://doi.org/10.14719/pst.2016.3.1.179

Association of Official Analytical Chemists (AOAC), 1990. Official methods of analysis of the AOAC International. Vol. 2. AOAC, Arlington, TX, USA, 1,298 pp.

Badu-Apraku, B. and Fakorede, M.A.B., 2017. Maize in sub-Saharan Africa: importance and production constraints. Advances in genetic enhancement of early and extra-early maize for sub-Saharan Africa. Springer, Cham, Switzerland. https://doi.org/10.1007/978-3-31964852-1_1

Baligar, V.C., Fageria, N.K. and He, Z.L., 2001. Nutrient use efficiency in plants. Communications in Soil Science and Plant Analysis 32: 921-950. https://doi.org/10.1007/978-3-319-10635-9

Beesigamukama, D., Mochoge, B., Korir, N.K., Fiaboe, K.K.M., Nakimbugwe, D., Khamis, F.M., Dubois, T., Subramanian, S., Wangu, M.M., Ekesi, S. and Tanga, C.M., 2020a. Biochar and gypsum amendment of agro-industrial waste for enhanced black soldier fly larval biomass and quality frass fertilizer. PLoS ONE 15: e0238154. https://doi.org/10.1371/journal.pone.0238154

Beesigamukama, D., Mochoge, B., Korir, N., Musyoka, M.W., Fiaboe, K.K.M., Nakimbugwe, D., Khamis, F.M., Subramanian, S., Dubois, T., Ekesi, S. and Tanga, C.M., 2020b. Nitrogen fertilizer equivalence of black soldier fly frass fertilizer and synchrony of nitrogen mineralization for maize production. Agronomy 10: 1395.

Beesigamukama, D., Mochoge, B., Korir, N.K., Fiaboe, K.K.M., Nakimbugwe, D., Khamis, F.M., Subramanian, S., Wangu, M.M., Ekesi, S., Kelemu, S. and Tanga, C.M., 2020c. Exploring black soldier fly frass as novel fertilizer for improved growth, yield, and nitrogen use efficiency of maize under field conditions. Frontiers in Plant Science 11: 574592. https://doi.org/10.3389/fpls.2020.574592

Beesigamukama, D., Mochoge, B., Korir, N.K., K.M. Fiaboe, K., Nakimbugwe, D., Khamis, F.M., Subramanian, S., Wangu, M.M., Dubois, T., Ekesi, S. and Tanga, C.M., 2021. Low-cost technology for recycling agro-industrial waste into nutrient-rich organic fertilizer using black soldier fly. Waste Management 119: 183-194. https:// doi.org/10.1016/j.wasman.2020.09.043 
Bernal, M.P., Alburquerque, J.A. and Moral, R., 2009. Composting of animal manures and chemical criteria for compost maturity assessment. A review. Bioresource Technology 100: 5444-5453. https://doi.org/10.1016/j.biortech.2008.11.027

Chia, S.Y., Tanga, C.M., Van Loon, J.J. and Dicke, M., 2019. Insects for sustainable animal feed: inclusive business models involving smallholder farmers. Current Opinion in Environmental Sustainabilty 41: 23-30. https://doi.org/10.1016/j.cosust.2019.09.003

Choi, S. and Hassanzadeh, N., 2019. BSFL Frass : a novel biofertilizer for improving plant health while minimizing environmental impact. The Candian Science Fair Journal 2: 41-46. https://doi.org/10.18192/ csfj.v2i220194146

De Groote, H., Vanlauwe, B., Rutto, E., Odhiambo, G.D., Kanampiu, F. and Khan, Z.R., 2010. Economic analysis of different options in integrated pest and soil fertility management in maize systems of western Kenya. Agriculture Economics 41: 471-482.

Diener, S., Zurbrügg, C., Roa Gutiérrez, F., Hong Nguyen, D., Morel, A., Koottatep, T. and Tockner, K., 2011. Black soldier fly larvae for organic waste treatment - prospects and constraints. In: Proceedings of the Waste Safe 2011 - $2^{\text {nd }}$ International Conference on Solid Waste Management in the Developing Countries. 13-15 February 2011. Khulna, Bangladesh, pp. 52-60. https://doi.org/10.1126/ science.335.6073.1166

Erickson, M.C., Islam, M., Sheppard, C., Liao, J. and Doyle, M.P., 2004. Reduction of Escherichia coli O157:H7 and Salmonella enterica serovar Enteritidis in chicken manure by larvae of the black soldier fly. Journal of Food Protection 67: 685-690. https:// doi.org/10.4315/0362-028X-67.4.685

Fageria, V.D., 2001. Nutrient interactions in crop plants. Journal of Plant Nutrition 24: 1269-1290. https://doi.org/10.1081/PLN100106981

Food and Agriculture Organisation (FAO), International Fund for Agricultural Development (IFAD), United Nations International Children's Emergency Fund (UNICEF), World Food Programme (WFP) and World Health Organisation (WHO), 2017. The state of food security and nutrition in the world 2017. Building resilience for peace and food security. FAO, Rome, Italy.

Gachene, C. and Kimaru, G., 2003. Soil fertility and land productivity: a guide for extension workers in the eastern Africa region. English Press Limited. Nairobi, Kenya

Gachimbi, L.N., Van Keulen, H., Thuranira, E.G., Karuku, A.M., De Jager, A., Nguluu, S., Ikombo, B.M., Kinama, J.M., Itabari, J.K. and Nandwa, S.M., 2005. Nutrient balances at farm level in Machakos (Kenya), using a participatory nutrient monitoring (NUTMON) approach. Land Use Policy 22: 13-22. https://doi.org/10.1016/j. landusepol.2003.07.002

Geng, Y., Cao, G., Wang, L. and Wang, S., 2019. Effects of equal chemical fertilizer substitutions with organic manure on yield, dry matter, and nitrogen uptake of spring maize and soil nitrogen distribution. PLoS ONE 14: e0219512. https://doi.org/10.1371/ journal.pone.0219512

Gibbon, D., Dixon, J. and Flores, D., 2007. Beyond drought-tolerant maize: study of additional priorities in maize. Report to generation challenge program. Impacts, Targeting and Assessment Unit, Centro Internacional de Mejoramiento de Maiz y Trigo, Mexico City, Mexico, 42 pp.
Gram, G., Roobroeck, D., Pypers, P., Six, J., Merckx, R. and Vanlauwe, B., 2020. Combining organic and mineral fertilizers as a climatesmart integrated soil fertility management practice in sub-Saharan Africa: a meta-analysis. PLoS ONE 15: e0239552. https://doi. org/10.1371/journal.pone.0239552

Green, T.R. and Popa, R., 2012. Enhanced ammonia content in compost leachate processed by black soldier fly larvae. Applied Biochemistry and Biotechnology 166: 1381-1387. https://doi.org/10.1007/s12010011-9530-6

Houben, D., Daoulas, G., Faucon, M.P. and Dulaurent, A.M., 2020. Potential use of mealworm frass as a fertilizer: impact on crop growth and soil properties. Scientific Reports 10: 4659. https:// doi.org/10.1038/s41598-020-61765-x

Inckel, M., Smet, P.D. and Tersmette, T., 2005. The preparation and use of compost, $7^{\text {th }}$ edition. Agrodok Publications, Wageningen, the Netherlands.

Jain, S., 2014. Organoleptic evaluation of recipes based on different varieties of maize. Indian Journal of Extension Education and Rural Development 22: 141-145.

Kagata, H. and Ohgushi, T., 2012. Positive and negative impacts of insect frass quality on soil nitrogen availability and plant growth. Population Ecology 54: 75-82. https://doi.org/10.1007/s10144011-0281-6

Kassie, M., Teklewold, H., Moti, J., Marenya, P. and Erenstein, O., 2015. Understanding the adoption of a portfolio of sustainable intensification practices in eastern and southern Africa. Land Use Policy 42: 400-411.

Kenyan Government, 2019. The regulation of wages. General amendment order 2018. Kenya gazette supplement No. 1. Kenya Government, Nairobi, Kenya.

Klammsteiner, T., Turan, V., Juárez, M.F.-D., Oberegger, S. and Insam, H., 2020. Suitability of black soldier fly frass as soil amendment and implication for organic waste hygienization. Agronomy 10: 1578. https://doi.org/10.3390/agronomy10101578

Kogbe, J.O.S. and Adediran, J.A., 2003. Influence of nitrogen, phosphorus and potassium application on the yield of maize in the savanna zone of Nigeria. African Journal of Biotechnology 2: 360-371.

Kumar, D. and Narayan J.A., 2013. Nutritional, medicinal and economical importance of corn: a mini review. Research Journal of Pharmaceutical Sciences 2: 7-8.

Lalander, C., Senecal, J., Gros Calvo, M., Ahrens, L., Josefsson, S., Wiberg, K. and Vinnerås, B., 2016. Fate of pharmaceuticals and pesticides in fly larvae composting. Science of Total Environment 565: 279-286. https://doi.org/10.1016/j.scitotenv.2016.04.147

Lalander, C.H., Fidjeland, J., Diener, S., Eriksson, S. and Vinnerås, B., 2015. High waste-to-biomass conversion and efficient Salmonella spp. reduction using black soldier fly for waste recycling. Agronomy for Sustainable Develpment 35: 261-271. https://doi.org/10.1007/ s13593-014-0235-4

Li, Q., Zheng, L., Qiu, N., Cai, H., Tomberlin, J.K. and Yu, Z., 2011. Bioconversion of dairy manure by black soldier fly (Diptera: Stratiomyidae) for biodiesel and sugar production. Waste Management 31: 1316-1320. https://doi.org/10.1016/j. wasman.2011.01.005 
Muchena, F.N., Onduru, D.D., Gachini, G.N. and De Jager, A., 2005. Turning the tides of soil degradation in Africa: capturing the reality and exploring opportunities. Land Use Policy 22: 23-31. https://doi. org/10.1016/j.landusepol.2003.07.001

Mucheru-Muna, M., Mugendi, D., Pypers, P., Mugwe, J., Kung'U, J., Vanlauwe, B. and Merckx, R., 2014. Enhancing maize productivity and profitability using organic inputs and mineral fertilizer in central Kenya small-hold farms. Experimental Agriculture 50: 250-269. https://doi.org/10.1017/S0014479713000525

Ndambi, O.A., Pelster, D.E., Owino, J.O., De Buisonjé, F. and Vellinga, T., 2019. Manure management practices and policies in sub-Saharan Africa: implications on manure quality as a fertilizer. Frontiers in Sustainable Food Systems 3: 29. https://doi.org/10.3389/ fsufs.2019.00029

Nsoanya, L.N. and Nweke, I.A., 2015. Effect of integrated use of spent grain and NPK $(20: 10: 10)$ fertilizer on soil chemical properties and maize (Zea mays L) growth. International Journal of Research in Agriculture and Forestry 2: 14-19.

Ojo, J.A., Olowoake, A.A. and Obembe, A., 2014. Efficacy of organomineral fertilizer and un-amended compost on the growth and yield of watermelon (Citrullus lanatus Thumb) in Ilorin Southern Guinea Savanna zone of Nigeria. International Journal of Recycling of Organic Waste in Agriculture 3: 121-125. https:// doi.org/10.1007/s40093-014-0073-z

Okalebo, J.R., Gathua, K.W. and Woomer, P.L., 2002. Laboratory methods of soil and plant analysis. A working manual, $2^{\text {nd }}$ edition. TSBF-CIAT and SACRED Africa, Nairobi, Kenya, 127 pp.

Onsongo, V.O., Osuga, I.M., Gachuiri, C.K., Wachira, A.M., Miano, D.M., Tanga, C.M., Ekesi, S., Nakimbugwe, D. and Fiaboe, K.K.M., 2018. Insects for income generation through animal feed: effect of dietary replacement of soybean and fish meal with black soldier fly meal on broiler growth and economic performance. Journal of Economic Entomology 111: 1966-1973. https://doi.org/10.1093/ jee/toy118

Palomba, I., 2016. Effects of $\mathrm{C}: \mathrm{N}$ ratio in cut-and-carry green manure and nitrogen application rate in organic potato production. MScthesis, Wageningen UR, Wageningen, the Netherlands, 31 pp.

Poveda, J., Jiménez-Gómez, A., Saati-Santamaría, Z., UsateguiMartín, R., Rivas, R. and García-Fraile, P., 2019. Mealworm frass as a potential biofertilizer and abiotic stress tolerance-inductor in plants. Applied Soil Ecology 142: 110-122. https://doi.org/10.1016/j. apsoil.2019.04.016

Quansah, G.W., 2010. Effect of organic and inorganic fertilizers and their combinations on the growth and yield of maize in the semideciduous forest zone of Ghana. Thesis, Kwame Nkrumah University of Science and Technology, Kumasi, Ghana, 162 pp.
Quilliam, R.S., Nuku-Adeku, C., Maquart, P., Little, D., Newton, R. and Murray, F., 2020. Integrating insect frass biofertilisers into sustainable peri-urban agro-food systems. Journal of Insects as Food and Feed 6: 315-322. https://doi.org/10.3920/jiff2019.0049

R Core Team, 2019. R: a language and environment for statistical computing. R Foundation for Statistical Computing, Vienna, Austria.

Rouf, S.T., Prasad, K. and Kumar, P., 2016. Maize - a potential source of human nutrition and health: a review. Cogent Food and Agriculture 2: 1-9. https://doi.org/10.1080/23311932.2016.1166995

Rufino, M.C., Tittonell, P., Van Wijk, M.T., Castellanos-Navarrete, A., Delve, R.J., De Ridder, N. and Giller, K.E., 2007. Manure as a key resource within smallholder farming systems: analysing farmscale nutrient cycling efficiencies with the NUANCES framework. Livestock Science 112: 273-287. https://doi.org/10.1016/j. livsci.2007.09.011

Sandhu, K.S., Singh, N. and Malhi, N.S., 2007. Some properties of corn grains and their flours I: physicochemical, functional and chapatimaking properties of flours. Food Chemistry 101: 938-946. https:// doi.org/10.1016/j.foodchem.2006.02.040

Shah, T., Prasad, K. and Kuma, P., 2015. Studies on physicochemical and functional characteristics of asparagus bean flour and maize flour. In Mishra, G.C. (ed.) Conceptual frame work \& innovations in agroecology and food sciences. Krishi Sanskriti Publications, New Delhi, India.

Stewart, Z.P., Pierzynski, G.M., Middendorf, B.J. and Vara Prasad, P.V., 2020. Approaches to improve soil fertility in sub-Saharan Africa. Journal of Experimental Botany 71: 632-641.

Richard, T. and Trautmann, N., 1996. C/N ratio. Cornell Waste Management Institute, Cornell University, Ithaca, NY, USA. Availablat at: http://compost.css.cornell.edu/calc/cn_ratio.html

Tully, K., Sullivan, C., Weil, R. and Sanchez, P., 2015. The state of soil segradation in sub-Saharan Africa: baselines, trajectories, and solutions. Sustainability 7: 6523-6552. https://doi.org/10.3390/ su7066523

Vanlauwe, B., Descheemaeker, K., Giller, K.E., Huising, J., Merckx, R., Nziguheba, G. and Wendt, J., 2015. Integrated soil fertility management in sub-Saharan Africa : unravelling local adaptation. Soil Journal 1: 491-508. https://doi.org/10.5194/soil-1-491-2015

Yuan, Z., Cao, Q., Zhang, K., Ata-Ul-Karim, S.T., Tan, Y., Zhu, Y., Cao, W. and Liu, X., 2016. Optimal leaf positions for SPAD meter measurement in rice. Frontiers in Plant Science 7: 719. https://doi. org/10.3389/fpls.2016.00719

Zahn, N.H., 2017. The effects of insect frass created by Hermetia illucens on spring onion growth and soil fertility. Msc-thesis, University of Stirling, Stirling, UK, 65 pp. 